\title{
Hubris syndrome
}

\author{
David Owen
}

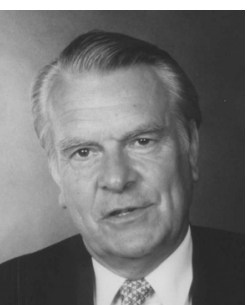

This article is based on the

Samuel Gee

Lecture given at the Royal College

of Physicians on

17 March 2008 by

Rt Hon Lord David

Owen CH FRCP and

is based on his

book In Sickness

and in power

(London: Methuen,

2008)

Clin Med

2008:8:428-32
ABSTRACT - Hubris syndrome is associated with power, more likely to manifest itself the longer the person exercises power and the greater the power they exercise. A syndrome not to be applied to anyone with existing mental illness or brain damage. Usually symptoms abate when the person no longer exercises power. It is less likely to develop in people who retain a personal modesty, remain open to criticism, have a degree of cynicism or well developed sense of humour. Four heads of government in the last 100 years are singled out as having developed hubris syndrome: David Lloyd George, Margaret Thatcher, George W Bush and Tony Blair.

KEY WORDS: intoxication, isolation. messianic, power

'Hubris' is not as yet an accepted medical term. The most basic meaning, developed in ancient Greece, is simply as a description of an act: a hubristic act was one in which a powerful figure, puffed up with overweening pride and self-confidence, treated others with insolence and contempt. The individual seemed to derive pleasure from using his power to treat others in this way, but such dishonouring behaviour was strongly condemned in ancient Greece. In a famous passage from Plato's Phaedrus, a predisposition to hubris is defined: 'When desire irrationally drags us toward pleasures and rules within us, its rule is called excess [hubris]'.

Hubristic behaviour has fascinated playwrights, no doubt because it provides the opportunity to explore human character within highly dramatic action. Shakespeare's Coriolanus is an excellent example. But the pattern of the hubristic career is one that will immediately strike a chord in anyone who has studied the history of political leaders. It is an occupational hazard for all leaders, whether political, business, military or academic, although not all such leaders develop the hubris syndrome. Many politicians at times, however, do manifest some characteristic of hubristic behaviour.

There are several defined categories of mental illness that may be related in part to a continuum around hubris syndrome: adult attention deficit/hyperactivity disorder (ADHD), substance abuse, which includes alcohol, hypomania, bipolar disorder, paranoid personality disorder, one of nine categories listed in the International classification of diseases (ICD)-10, and narcissistic personality disorder (NPD), one of 10 categories listed in Diagnostic and statistical manual of mental disorders (DSM-IV). Most of these have established genetic linkage..$^{2-9}$ A linkage which 'confer vulnerability to disorder' but not necessarily the disorder itself. Peter Tyrer argues they would be better called personality diatheses. $^{10}$

Personality disorders tend to appear in late childhood or adolescence and continue into adulthood. A study in 2006 found that they affect nearly $4.4 \%$ of people in the UK. ${ }^{11}$ Hubris syndrome is different in that it usually manifests itself later in life and should not therefore be seen as a personality disorder but as an illness of position as much as of the person.

\section{Hubris syndrome}

Hubris syndrome is inextricably linked with power, indeed power is a prerequisite, and when power passes the syndrome will normally remit. The outcome seems to bear some relationship to the length of time that the individual has been in command. It evolves and is best understood as being a continuum with normal behaviour. The behavioural symptoms in a head of government which might trigger the diagnosis of hubris syndrome typically grow in strength and at least three or four symptoms from the following tentative list should be present before any such diagnosis be contemplated:

- a narcissistic propensity to see the world primarily as an arena in which they can exercise power and seek glory rather than as a place with problems that need approaching in a pragmatic and non-self-referential manner

- a predisposition to take actions which seem likely to cast them in a good light, taken in part in order to enhance their image

- a disproportionate concern with image and presentation

- a messianic manner of talking about what they are doing and a tendency to exaltation in speech and manner

- an identification of themselves with the nation to the extent that they regard the outlook and interests of the two as identical 
- a tendency to talk of themselves in the third person or use of the royal 'we'

- excessive confidence in their own judgement and contempt for the advice or criticism of others

- exaggerated self-belief, bordering on a sense of omnipotence, in what they personally can achieve

- a belief that rather than being accountable to the mundane court of colleagues or public opinion, the real court to which they answer is much greater: History or God; often accompanied by an unshakeable belief that in that court they will be vindicated

- restlessness, recklessness and impulsiveness

- loss of contact with reality, often associated with progressive isolation

- a tendency to allow their 'broad vision', especially their conviction about the moral rectitude of a proposed course of action, to obviate the need to consider other aspects of it, such as its practicality, cost and the possibility of unwanted outcomes

- a consequent type of incompetence in carrying out a policy, which could be called hubristic incompetence. This is where things go wrong precisely because too much selfconfidence has led the leader not to worry about the nuts and bolts of a policy. It can be allied to an incurious nature. It is to be distinguished from ordinary incompetence, where the necessary detailed work on the complex issues involved is engaged in but mistakes in decision-making are made nonetheless.

The key external factors in hubris syndrome would seem to be: holding substantial power; minimal constraint on the leader exercising such personal authority; and the length of time they stay in power. An atmosphere of omnipotence can easily grow around any leader, but a head of government is particularly vulnerable. Even democratically elected ones are surrounded by deference and hierarchy within the whole of the government machine. Their views are seen to represent the government. More than most, political leaders' views are recycled back and alternative views can easily be ignored or dismissed as heretical. A 'bunker mentality' easily builds up around them.

\section{Hubristic personality}

A hubristic personality is much more common in heads of government, whether democratic or not, than is often realised. Barbara Tuchman's definition of political folly is 'a perverse persistence in a policy demonstrably unworkable or counterproductive.'12 Bertrand Russell wrote:

The concept of 'truth' as something dependent upon facts largely outside human control has been one of the ways in which philosophy hitherto has inculcated the necessary element of humility. When this check upon pride is removed, a further step is taken on the road towards a certain kind of madness - the intoxication of power. ${ }^{13}$
Democratic societies, especially those which have evolved out of absolute monarchies, have developed systems of checks and balances to try to protect themselves from such leaders. But these mechanisms - cabinet, parliament and the media - are not always effective. Under despotic leaders, where there are no democratic controls and few internal mechanisms, short of a coup, to remove them there is often little that can be done. External condemnation and international sanctions have, so far, proved of only limited value while external military force has had questionable success.

Many people believe that all politicians are hubristic. This is not the case. Four politicians in my lifetime whom I admire clearly had an inner image of themselves which prevented them from being intoxicated by power: President Harry Truman; Prime Minister Clement Attlee; Chancellor Helmut Schmidt and Prime Minister James Callaghan all achieved remarkable and rather unexpected political success, but it did not go to their heads.

There is a mismatch between what the press and public talk about as mental illness and a medically diagnosed mental disorder. Psychopathic behaviour has now been defined as a specific range of personality disorders and megalomania as delusions of grandeur. Heads of government who had a hubristic personality in the last century can be found among democrats as well as dictators.

Abraham Lincoln is a most interesting case of how a leader's qualities can be forged through their depression. He had two major breakdowns and his depression in his 20s became more persistent in his 30s but a recent study found no evidence of mania, although the author felt it possible that Lincoln had hypomania, characterised by heightened energy. ${ }^{14}$

Franklin Roosevelt looked as if he might be taken over by hubris when, in 1937, he fought and lost a battle with Congress over his Judicial Branch Reorganization Plan, attempting to change the procedure for the nomination of justices to the Supreme Court. One has to recognise FDR's personal determination, ruthlessness, guile, optimism, and fortunately, he also had a sense of humour and a certain cynicism, which meant he never lost his moorings in the democratic system. Those qualities, in part the product of his earlier polio, gave him the political authority to conquer the 1930s economic depression, mobilise his country for war and to win that war in the interests of the whole world. I do not believe FDR developed hubris syndrome.

American presidents who were hubristic were Theodore Roosevelt and Lyndon Johnson, yet both have been retrospectively diagnosed as also having had bipolar disorder. ${ }^{15}$ Woodrow Wilson and Richard Nixon were increasingly hubristic, but in addition Wilson suffered from dementia and Nixon became an alcoholic. John F Kennedy was hubristic at times but suffered from Addison's disease and in addition to his replacement cortisol and testosterone were recreational drugs. Kennedy was too cynical and humorous to develop hubris syndrome.

Dictators who were hubristic include Stalin, Mao, Pol Pot, Amin and Mugabe, to name only a few. Benito Mussolini was hubristic but may well have had bipolar disorder, and so may Mao Zedong. Ian Kershaw aptly titled the two volumes of his 
biography of Adolf Hitler Hubris and Nemesis. ${ }^{16,17}$ Hitler had a definite progression in his hubris from 1936 to 1941, and is a candidate for the syndrome, but he had many other complex aspects to his personality. Hypomania was a feature of Nikita Khrushchev's behaviour, who did get more hubristic while in office, and also had depressive episodes. He was described as:

Elated, energetic, self-promoting, witty and grandiose...overtly cheerful, highly social, given to idealisation of others, work addicted, flirtatious and articulate while covertly...guilty about aggression toward others, incapable of being alone...corruptible and lacking a systematic approach in cognitive style... Grand schemes, racing thoughts, extended freedom from ordinary physical requirements such as food and sleep...constantly ' $u p$ ' - until exhaustion eventually sets in. ${ }^{18}$

On 14 October 1964 Khrushchev was removed by the collective leadership of the Presidium, although it was described as 'retirement'.

\section{Hubris syndrome and heads of government}

What interests me are those heads of government who are 'normal' on taking office with no history of depression or mania but who develop hubris with a loss of 'capacity' in the mental health meaning of the word capacity. Nemesis usually, though not always, follows.

Any assessment of hubris syndrome is made harder by the fact that some of its characteristics - supreme self-confidence, the readiness to disregard advice, let alone the more obviously dubious characteristics of impulsiveness or recklessness, can be advantageous to leaders in some situations, albeit deleterious in the wider context. To an extent, these characteristics may have contributed to them emerging from the pack to become leaders.

I judge the following four heads of government as those who developed hubris syndrome while in office: Lloyd George, Margaret Thatcher, George W Bush and Tony Blair. ${ }^{19}$

\section{David Lloyd George}

Tracing Lloyd George's period as prime minister one can see two distinct phases - December 1916-June 1919 and July 1919October 1922. The mistakes and errors Lloyd George began to make after July 1919 were born out of hubristic actions. Firstly, he was mesmerised by the world stage. After he signed the Treaty of Versailles on 28 June 1919, having negotiated it for months in Paris, he continued to spend an inordinate amount of time hammering out difficult issues in special conferences. He attended no fewer than 33 between 1919 and $1922 .{ }^{20}$ Secondly, he came to believe he was indispensable. By 1920, Winston Churchill was complaining as war secretary that the prime minister had virtually taken over the running of the foreign office and historians have written about these years as the start of a 'presidential government.'.

A more balanced view of Lloyd George's postwar prime ministership, chronicling some of its undoubted achievements, comes from the historian Kenneth O Morgan, 'For all its failures, the Lloyd George Coalition of 1918-22, alone of peacetime
British governments this century, tried to harness political consensus for positive ends. ${ }^{22}$ But Morgan saw that the seeds of Lloyd George's destruction were traceable to his unconstrained personality. He writes of 'the dangers of Caesarism...intuitive, erratic diplomacy and confused, ill-prepared encounters.'. ${ }^{22}$

\section{Margaret Thatcher}

Margaret Thatcher's place in history is assured. It was also recognised during her lifetime by her statue being placed in the member's lobby of the House of Commons as one of a set of four alongside Lloyd George, Churchill and Attlee. Yet by 1989 I felt that her grasp of the realities in which she was operating seemed to desert her. Poll tax was deeply unpopular. When the Berlin Wall came down in November 1989, she refused to recognise that reunification of East and West Germany would come immediately onto the political agenda. An underlying fear of a larger Germany developed into her privately talking emotionally about a Fourth Reich. She warned George Bush Sr that if we are not careful, the Germans will get in peace what Hitler couldn't get in the war', a quite extraordinary remark. ${ }^{23}$ The fact that she totally miscalculated the speed of the political imperative that was driving German reunification was one of the signs that her political judgement was being jeopardised by her political prejudices and that her self-confidence was overriding her caution. More seriously, she alienated and lost her chancellor of the exchequer, Nigel Lawson, by refusing to acknowledge that in retaining her personal economic adviser, whose opposition to the chancellor's economic policies became public knowledge, she had made Lawson's position impossible. Towards the end of her premiership, one of her backbenchers said that she was now 'off her trolley'. One of her own ministers told a journalist that she had become 'mad, completely mad'. ${ }^{24}$ Full-blown hubris became evident when, on 30 October 1990, she returned to the House of Commons after a meeting in Rome of European Union heads of government, where she had issued a series of statements in a press conference on what she would not put up with. The scene in the Commons was well described by the Guardian's political commentator, Hugo Young:

it became in its monosyllabic brutality, the rubric of one of her most famous parliamentary moments, leaping with rage, ringing round the chamber, startling even those who in eleven years had much experience of the Thatcher vocabulary on Europe. 'No...no...no,' she bawled, her eye seemingly directed to the fields and seas, the hills and the landinggrounds, where the island people would never surrender. ${ }^{25}$

Geoffrey Howe, had been her chancellor of the exchequer and foreign secretary but was demoted to leader of the House of Commons. She became increasingly contemptuous of his mild manner and her willingness to scorn and humiliate him in cabinet embarrassed even her thickest-skinned colleagues. This was hubris in its rawest form. Nemesis followed Howe's resignation speech, all the more devastating because of the modest manner of its delivery. Within a month she had been forced out of office by Conservative members of parliament (MPs). 


\section{George W Bush}

Revealingly, an American book on the Iraq War was simply called Hubris. ${ }^{26}$ On 1 May 2003, George W Bush, dressed like a Hollywood actor in flying gear, flew onto the aircraft carrier Abraham Lincoln off the coast of California and stood on the flight deck to celebrate victory in Iraq, the ship's control tower emblazoned with the slogan 'Mission accomplished'. It was a hubristic act of a very high order. It was also a contemptuous, if unintended, insult to the troops in the field, who knew all too well the slogan's patent absurdity. Donald Rumsfeld had the sense to dissuade Bush from actually using the phrase in his speech but even so Bush did say, 'In the battle for Iraq, the United States and our allies have prevailed'. It is incomprehensible that there was no serious planning for the aftermath of the invasion. No readiness until 2007 to increase troop levels when a surge of extra Americnan forces had some effect.

\section{Tony Blair}

A warning sign of Tony Blair's developing hubris was the astonishing speech that he gave to the Labour Party conference immediately after September 11 2001, described by Kenneth Morgan, now Lord Morgan:

Blair seemed a political colossus, half-Caesar, half-Messiah. Equally, as times became tough following the Iraq imbroglio, he became an exposed solitary victim, personally stigmatised as in the 'cash for peerages' affair. Blair discovered, like Lloyd George and Thatcher before him, that British politics do not take easily to the Napoleonic style. ${ }^{27}$

Blair's incompetence, highlighted over Iraq, was triggered by three characteristic symptoms of hubris: excessive self-confidence, restlessness and inattention to detail. A self-confidence that exclusively reserves decision-making to itself, does not seek advice and fails to listen to or is contemptuous of the wisdom of others, particularly if it conflicts with the leader's own viewpoint, is hubristic. This combined with an energy restless for action and a readiness to intervene on the basis of the broader picture rather than the detailed study of all the relevant information, makes serious mistakes almost inevitable. This was also the case in Blair's handling of foreign affairs after September 11: the misjudgements were those of hubristic incompetence.

Narcissism in actor-politicians makes the hero role all but irresistible. An important trait of Blair's personality concerns his view of himself, in that he thinks he is always good. This is so strong in Blair that he is a latter-day antinomian - the name given to the 16th-century heretics who believed that 'to the pure all things are pure', meaning that whatever they did was, by definition, pure. ${ }^{28}$ Someone who believes they cannot act badly lacks the constraint on behaviour which the fear that they might otherwise impose on them. They believe, particularly, that they cannot lie, so shading the truth can easily become a habit. In 2003, Blair grandiosely boasted that he personally had 'got rid of four dictators in Kosovo, Sierra Leone, Afghanistan and Iraq. ${ }^{29}$

It was to become a feature of both Bush and Blair that neither showed much attention to process or detail, nor were they straight with the facts. Blair made up for what he lacked in power by his far greater verbal fluency and passionate language. His political importance was that he reinforced Bush's 'born again' Christian beliefs and prejudices in the period after the invasion of Afghanistan, in the run-up to and in the aftermath of the invasion of Iraq until the autumn of 2006. It was a form of folie à deux.

Blair never understood why the country would not 'move on' over Iraq. His hubris revived after the 2005 general election, though never becoming as marked as in 2001-3. His obsession about his legacy delayed decisions over the date of his promised resignation until Labour MPs in September 2006 forced him to say he would go before the following year's party conference. He conveyed the impression that he and he alone, with a unit in Downing Street, could put into effect the programme of change his government had embarked upon for education and health, but as over military matters his constant intervention destabilised these services, demoralised the professional staff and had the effect of reducing the benefits of the allocation of substantially increased funds: 'Blair had one all-pervasive weakness, his wish to exercise central control. ${ }^{30}$

\section{Avoiding hubris syndrome}

The decisive leaders who are most likely to avoid succumbing to hubris are usually those who are careful to retain a personal modesty as they stay in power, to keep their previous lifestyle and to eschew the trappings of power. They try to consult carefully even if during that process they may not alter their opinions. Above all, in a democracy, they accept that the inbuilt institutional checks and balances should be scrupulously respected and make little or no attempt to circumvent them, whether in cabinet or parliament. External factors like institutional constraints, valued confidants unafraid to criticise, such as wives, husbands, colleagues or friends, help curb hubris syndrome. As do internal factors such as humour, cynicism, self criticism and even humility.

\section{Pathogenesis}

Hubris syndrome is not yet a diagnostic category of accepted mental illness but it probably stems from a set of genetically codetermined predisposed personality traits. To the psychiatrist any potential new syndrome is likely to be an interaction between genes and environment or nature and nurture. Early biology and upbringing provide the basis of personality which can then be expressed, or not, depends on constraints or opportunities.

To the lay person looking for chemical explanations of hubris, adrenaline or dopamine are often cited. To the neuroscientist, dopamine may be relevant because it is seen as central to issues of reward and motivated behaviour and is linked to human drive, novelty seeking and activation. But the dopamine cycle in the brain from experiments in rats is highly complex and needs to be interpreted with caution. ${ }^{31}$ Neuroscientists are also looking at other circuits in the brain governed by the neurotransmitters, such as glutamate and gamma-aminobutyric acid (GABA), 
which both play major roles in modulating the intensity of dopamine response to drugs and other stimuli.

It is my hope that neuroscientists will consider hubris syndrome within the broad basis of a systems-orientated approach and examine whether prolonged leaders' stress associated with noradrenergic and dopamine systems with some predisposing factors may affect this system in ways not dissimilar to the resetting experienced by the long distance runner after a prolonged period of running. A resetting of the dopamine system might provide an explanatory hypothesis underpinning of the hubris syndrome.

I believe that the neuroscientists will ultimately provide an explanation of why some leaders succumb to hubris while others do not. There may well be no medical cure, but it is becoming ever clearer that hubris syndrome is a greater threat than conventional illness to the quality of leadership and the proper government of our world.

\section{References}

1 Plato. Phaedrus, 238a. In: Euthyphro/Apology/Crito/Phaedo/ Phaedrus, trans Fowler HN. Cambridge, MA: Harvard University Press, 1914.

2 Levy F, Hay DA, McStephen M, Wood C, Waldman I. Attention-deficit hyperactivity disorder: a category or a continuum? Genetic analysis of a large-scale twin sudy. J Am Acad Child Adolesc Psychiatry 1997;36: $737-44$.

3 Kalbag AS, Levin FR. Adult ADHD and substance abuse: diagnostic and treatment issues. Subst Use Misuse 2005;40:1955-81, 2043-8.

4 Brady KT, Sinha R. Co-occuring mental and substance use disorders: The neurobiological effects of chronic stress. Am J Psychiatry 2005; $162 ; 1483-93$.

5 Albanese MJ, Clodfelter Jr RC, Pardo TB, Ghaemi SN. Underdiagnosis of bipolar disorder in men with substance use disorder. J Psychiatr Pract 2006;12:124-7.

6 Krishnan KRR. Psychiatric and medical comorbidities of bipolar disorder. Psychosom Med 2005;67:1-8.

7 Faraone-Stephen V, Glatt-Stephen J, Tsuang-Ming T. The genetics of pediatric-onset bipolar disorder. Biol Psychiatry 2003;53:970-7.

8 Stevenson J, Langley K, Pay H et al. Attention deficit hyperactivity disorder with reading disabilities: preliminary genetic findings on the involvement of the ADRA2A gene. J Child Psychol Psychiatry 2005;46: 1081-8.

9 Benis AM. Narcissism: a genetic trait; NPA theory of personality types based on Mendelian genetics; Caricatures of the NPA character types. 2004. http://narcissism.homestead.com
10 Tyrer P. Personality diathesis: a superior explanation than disorder. Psychol Med 2007;37:1521-5.

11 Coid J, Yang M, Tyrer P, Roberts A, Ullrich S. Prevalence and correlates of personality disorders in Great Britain. Br J Psychiatry 2006; 188:423-31.

12 Tuchman B. The march of folly: from Troy to Vietnam. New York: Ballantine, 1985.

13 Russel B. History of Western pilosophy, 2nd edn. London: George Allen and Unwin, 1961:782.

14 Shenk JW. Lincoln's melancholy: how depression challenged a president and fuelled his greatness. Boston: Houghton Mifflin, 2005.

15 Davidson JRT, Connor KM, Swartz M. Mental illness in US presidents between 1776 and 1974: a review of biographical sources. J Nerv Ment Dis 2006;194:47-51.

16 Kershaw I. Hitler 1889-1936: Hubris. London: Allen Lane, 1998.

17 Kershaw I. Hitler 1936-1945: Nemesis. London: Allen Lane, 2000.

18 Wedge B. Khrushchev at a distance: a study of public personality. Trans-Action 1968L24-8.

19 Owen D. In sickness and in power: illness in heads of government during the last 100 years. London: Methuen and New York: Praeger, 2008.

20 MacMillan M. Paris 1919: six months that changed the world. New York: Random House, 2002:188.

21 Lloyd George R. David and Winston. London: John Murray, 2005:164.

22 Morgan KO. Consensus and disunity: the Lloyd George coalition government 1918-1922. Oxford: Clarendon Press, 1979.

23 Bush G, Scowcroft B. A world transformed. New York: Alfred A Knopf, 1998:249.

24 Quoted in Stephens P. Blairism will outlive the departure of a battered Blair. Financial Times, 9 February 2007.

25 Young H. This blessed plot: Britain and Europe from Churchill to Blair. London: Macmillan, 1998:368.

26 Isikoff M, Corn D. Hubris: the inside story of spin, scandal, and the selling of the Iraq War. New York: Crown, 2006.

27 Morgan K. The judgement of history. Parliamentary Monitor 2007; 149:16-17.

28 Wheatcroft G. The tragedy of Tony Blair. Atlantic Monthly, June 2004.

29 Tony Blair speaking to Steve Richards, chief political commentator for the Independent and presenter of GMTV's Sunday Programme, October 2003.

30 Barber M. Instruction to deliver: Tony Blair, public services and the challenge of achieving targets. London: Politico's, 2007.

31 Bjørklund A, Dunnett SB. Fifty years of dopamine research. Trends Neurosci 2007;30:185-7. 